bioRxiv preprint doi: https://doi.org/10 1101/2021.04 19.440383; this version posted April 19, 2021. The copyright holder for this preprint (which was not certified by peer review) is the author/funder, who has granted bioRxiv a license to display the preprint in perpetuity. It is made available under aCC-BY-NC-ND 4.0 International license.

\title{
1 A biosensor to gauge protein homeostasis resilience differences in the nucleus compared to
} cytosol of mammalian cells

3 Candice B. Raeburn ${ }^{1}$, Angelique Ormsby ${ }^{1}$, Nagaraj S. Moily ${ }^{1}$, Dezerae Cox ${ }^{1}$, Simon Ebbinghaus ${ }^{2}$, Alex Dickson $^{3}$, Gawain McColl ${ }^{4}$ and Danny M. Hatters ${ }^{1, *}$

$5 \quad{ }^{1}$ Department of Biochemistry and Pharmacology; and Bio21 Molecular Science and Biotechnology Institute, The University of Melbourne, VIC 3010. Australia

$7 \quad{ }^{2}$ Physical and Theoretical Chemistry, TU Braunschweig, 38106 Germany and Braunschweig Integrated Centre of Systems Biology, 38106 Germany

${ }^{3}$ Department of Biochemistry \& Molecular Biology, Michigan State University, East Lansing, MI, 48824, USA

${ }^{4}$ Melbourne Dementia Research Centre, Florey Institute of Neuroscience and Mental Health and University of Melbourne, Parkville, VIC 3052, Australia.

*Correspondence: dhatters@unimelb.edu (D.M. Hatters).

\section{Abstract}

An extensive network of chaperones and other proteins maintain protein homeostasis and guard against inappropriate protein aggregation that is a hallmark of neurodegenerative diseases. Using a fluorescence resonance energy-based biosensor that simultaneously reports on intact cellular chaperone holdase activity and detrimental aggregation propensity, we investigated the buffering capacity of the systems managing protein homeostasis in the nucleus of the human cell line HEK293 compared to the cytosol. We found that the nucleus showed lower net holdase activity and reduced capacity to suppress protein aggregation, suggesting that the nuclear quality control resources are less effective compared to those in the cytosol. Aggregation of mutant huntingtin exon 1 protein (Httex1) in the cytosol appeared to deplete cytosolic chaperone supply by depleting holdase activity. Unexpectedly, the same stress increased holdase activity in the nucleus suggesting that proteostasis stress can trigger a rebalance of chaperone supply in different subcellular compartments. Collectively the findings suggest the cytosol has more capacity to manage imbalances in proteome foldedness than the nucleus, but chaperone supply can be redirected into the nucleus under conditions of proteostasis stress caused by cytosolic protein aggregation. 
bioRxiv preprint doi: https://doi.org/10.1101/2021.04.19.440383; this version posted April 19, 2021. The copyright holder for this preprint (which was not certified by peer review) is the author/funder, who has granted bioRxiv a license to display the preprint in perpetuity. It is made available under aCC-BY-NC-ND 4.0 International license.

\section{Introduction}

Protein homeostasis involves a network of quality control systems that ensures the proteome is properly translated, folded, delivered to the correct cellular location and turned over at appropriate times. When protein homeostasis becomes unbalanced, proteins become prone to misfolding leading to their mislocalisation and accumulation as aggregates $(1,2)$. The imbalance of protein homeostasis is hypothesized to underlie the inappropriate protein misfolding and aggregation that arise in the brain of patients with common neurodegenerative diseases including Alzheimer's, Parkinson's, Huntington's and motor neuron diseases $(3,4)$. Tools that can measure proteostasis imbalance therefore offer capacity to explore the mechanisms involved.

Previously we developed a method that enabled a measure of the effectiveness of the quality control system in maintaining protein homeostasis (5). The method involved the use of a biosensor that comprised of a model protein that engages with protein quality control machinery such as chaperones. The biosensor reported on amount of the model protein bound to quality control proteins (which we call hereon call holdase activity) and on the ability of quality control proteins to repress inappropriate protein aggregation of the model protein. The model protein was a catalytically inactive variant of the prokaryotic RNAse barnase. Unfolded barnase is both permissive to aggregation and able to bind to Hsp70 and Hsp40 family chaperones (6). Barnase folding resembles a 2-state mechanism and the proportion of unfolded barnase relative to folded barnase can be predictably tuned by mutation (7). Hence a panel of barnase variants enable different biosensors tuned to different ratios of folded versus unfolded proteins. When the biosensor is expressed in cells the proportion of folded proteins can be measured by fluorescence resonance energy transfer (FRET) through N-and C- terminal fusions to fluorescent protein donors and acceptors (Fig 1A). We previously showed that the abundances of unfolded barnase is increased in cells relative to that predicted by analysis of purified proteins due to quality control machinery forming complexes with the unfolded-like conformations of the biosensor and partitioning it from the equilibrium of folding (6). Therefore, alterations in quality control levels influence the total abundance of unfolded-like barnase, which we can detect by FRET, and therefore determine changes in the overall quality control supply available as a measure of proteostasis capacity.

The amount of biosensor aggregation can also provide a measure of overall chaperone activity. Our prior work devised a strategy that quantitatively measured aggregation as a complementary approach to foldedness (6). Here, we applied our biosensor system to examine how proteostasis balance is affected specifically within the nucleus and cytosol. We examine these local proteostasis changes that result from different triggers of stress either globally to the cell or locally within the cytoplasm or nucleus. 
bioRxiv preprint doi: https://doi org/10 1101/2021.04 19.440383; this version posted April 19, 2021. The copyright holder for this preprint (which was not certified by peer review) is the author/funder, who has granted bioRxiv a license to display the preprint in perpetuity. It is made available under aCC-BY-NC-ND 4.0 International license.

Results

\section{Generation of nuclear targeted biosensors and validation of folding stabilities}

The biosensor system comprises a suite of constructs whereby the barnase moiety has been mutated to display different standard free energies of folding $\left(\Delta G_{F}^{0}\right)$, which define the thermodynamic equilibrium of folding $K_{f}$ (Fig 1B). These constructs contained a nuclear export sequence (NES), which leads to them being restricted to a cytosolic localization (6). To direct the constructs to the nucleus we removed the NES and fused a nuclear localization sequence (NLS) from the SV40 protein to the $\mathrm{N}$-terminus (Fig 1A; Table $\mathbf{1}$ for sequences used). The biosensor containing wild-type* $\left(W T^{*}\right.$ ) barnase (which is marked with * to denote it contains the catalytic inactivation mutation H102A that is used in all our constructs) was efficiently targeted into the nucleus (Fig 1C). All mutants of barnase showed a similar result (not shown).

Because the NLS and NES could themselves affect the folding equilibrium, we measured their effect on folding by a urea denaturation curve which showed no noticeable difference (Fig 1D). Hence, we concluded that the biosensors with NLS and NES are amenable to directly measure and compare protein homeostasis balances between the cytosol and nucleus.

The strategy to monitor both the abundances of unfolded barnase and aggregation behaviour involved a flow cytometry protocol we previously developed (6). In essence, cells expressing the biosensor bifurcate into two distinct FRET populations when cells are gated on acceptor fluorescence versus donor fluorescence. The donor fluorescence levels are proportional to expression level and FRET and both are approximately linearly dependent on the acceptor fluorescence. One of the populations comprises a "lower slope" FRET population that contains cells with only soluble barnase biosensor (i.e. a mixture of medium and low FRET states; Fig 1A and E), whereas the other contains an "upper slope" FRET population, which contains cells with aggregated biosensor (i.e. dominated by high FRET states) (6). The gradient of the lower slope population is proportional to the actual FRET value and hence informative to the abundance of unfolded barnase versus folded barnase (i.e. the average signal of low and medium FRET states from Fig 1A). We had previously shown that quality control machinery such as Hsp70 and Hsp40 proteins HSPA8 and DNAJB1, respectively, can bind to unfolded biosensor and hold it in an unfolded-like state that has a low FRET signal (6) as summarized conceptually in Fig 1A. This binding creates a pool of chaperonebound biosensor that is partitioned from the equilibrium of folding. Greater partitioning leads to lower FRET signals, which can thus be used as a measure of the capacity of the quality control system to engage with the biosensor. 
bioRxiv preprint doi: https://doi org/10 1101/2021.04 19.440383; this version posted April 19, 2021. The copyright holder for this preprint (which was not certified by peer review) is the author/funder, who has granted bioRxiv a license to display the preprint in perpetuity. It is made available under aCC-BY-NC-ND 4.0 International license.

First, we examined whether the cytosolic and nuclear environments differentially affected the FRET readouts. This was achieved by expressing a FRET construct in which barnase was replaced with a short linker sequence that was not expected to be affected by changes in conformation or other ligand binding events. As such this linker should render the biosensor insensitive to folding-related effects and hence measures off-target influences on FRET signal as previously described (6). The linker control revealed a small (1.7\%) but significant ( $p<0.0001$, Student's t-test; 2 -tailed) decrease in FRET in the nucleus compared to the cytosol between the NLS and NES tagged variants (Fig 2A). To correct for this influence, all the subsequent analyses involving the barnase biosensors were corrected for differences using the NLS and NES linker construct controls.

Next, we examined the effectiveness of protein quality control systems to interact with the biosensor in the nucleus versus the cytosol. For this we examined four previously characterized mutants of barnase in addition to wild-type* that have variable $\Delta G^{0}{ }_{F}$ values and therefore different proportions of folded to unfolded barnase at equilibrium (Fig 1B). After correction for off-target FRET changes with the linker control, all nuclear-targeted biosensor variants had overall significantly higher FRET values for the lower slope populations than the cytosol-targeted biosensors, except for the most destabilised variant (I25A I96G), which is predicted to be substantially unfolded and therefore possibly outside the dynamic range that can be detected (Fig 2B). The higher FRET values in the nucleus are therefore indicative of less unfolded-like barnase conformations being held in complex with chaperones that would otherwise be partitioned from the equilibrium of folding. The results therefore suggested that the pool of chaperones that can bind to the biosensor is lower in the nucleus than the cytosol.

To examine the aggregation propensity of the barnase biosensors, we applied our previously devised method of determining the concentration of barnase at which $50 \%$ of the cells contain aggregates $\left(A_{50 \%}\right)(6) . A_{50 \%}$ values are derived from plots of the proportions of cells partitioning in the upper slope for a given expression level of barnase in cells (Fig 2C-D). Consistent with prior findings (6), $W T^{*}$ barnase did not aggregate and the less stable mutants (i.e. those with higher $\Delta G^{0}{ }_{F}$ values) were more sensitive to aggregation as determined by lower $A_{50 \%}$ values (Fig 2D). For all the barnase variants that aggregated, the $A_{50 \%}$ values were lower in the nucleus compared to the cytosol (Fig $\mathbf{2 C}$ D). These results indicated that barnase is inherently more aggregation prone in the nucleus than the cytosol, and therefore strengthens the conclusion that there are less quality control proteins in the nucleus that are able to bind to and stabilize barnase and prevent aggregation.

Hsp70 and Hsp40 chaperone systems more robustly mitigate unfolded proteins from aggregating in the cytosol than the nucleus 
bioRxiv preprint doi: https://doi org/10 1101/2021.04 19.440383; this version posted April 19, 2021. The copyright holder for this preprint (which was not certified by peer review) is the author/funder, who has granted bioRxiv a license to display the preprint in perpetuity. It is made available under aCC-BY-NC-ND 4.0 International license.

$131 \mathrm{Hsp70}$ isoforms HSPA1B and HSPA8 were previously found in immunoprecipitation experiments as

132 major chaperone interactors to the destabilized barnase mutants (6). We found that related Hsp70

133 family member HSPA1A could modulate both the amount of unfolded-like barnase and the amount

134 of barnase aggregation, suggesting it could bind to and stabilize an unfolded-like conformation of

135 barnase (6). While these Hsp70 isoforms are highly abundant in the cytosol (8), it was unclear as to

136 how modulating their supply might propagate changes in the nucleus or cytosol.

137 To examine this question, we co-transfected HSPA1A and a specific Hsp40 cofactor DNAJB1 (9) with

138 the barnase biosensors and analysed the cells after 48 hours culture. The transfected HSPA1A and

139 DNAJB1 showed a mostly cytosolic enrichment (Fig 3A). The co-transfected chaperones significantly

140 reduced the biosensor lower slope gradients in the cytosol (Fig 3B), consistent with a greater

141 abundance of chaperone bound to unfolded barnase. The treatments also increased the $A_{50 \%}$ values

142 indicating that the chaperones effectively suppressed inappropriate aggregation (Fig $\mathbf{3 C}$ ). However,

143 these effects appeared more muted in the nucleus indicating that chaperone overexpression

144 preferentially deepens the pool of chaperone supply in the cytosol, which likely is explained by the

145 transfected chaperone being mostly restricted to the cytosol.

146 To further probe the role of Hsp70 activity we inhibited Hsp70 on cells (without overexpressed

147 chaperones) using the small molecule inhibitor VER-155008, which competitively binds to the ATP-

148 binding pocket of Hsp70 family proteins and impairs substrate binding (10). This treatment increased

149 the FRET values of the lower slope populations in the nucleus but not the cytosol (Fig 3D). This result

150 suggested that while Hsp40 and 70 proteins are more effective at binding barnase in the cytosol,

151 there was higher redundancy and flexibility in the cytosol to absorb a reduced Hsp70 activity than in

152 the nucleus. Hence the network appeared more vulnerable to collapse in the nucleus upon stresses

153 to proteostasis systems. However, the increased sensitivity to proteostasis imbalance in the nucleus

154 was not seen in terms of aggregation. Indeed, aggregation of the biosensor was far more

155 disproportionately enhanced in the cytosol than the nucleus (Fig 3E). These findings suggested that

156 the correlation of holdase activity and aggregation can be decoupled when specific elements of the

157 proteostasis network are impaired and that this effect may arise through redundant holdase activity

158 in the cytosol from non-Hsp70 chaperones that are overall less effective at preventing aggregation

159 than Hsp70.

160 Aggregation of mutant Htt exon 1 in the cytosol propagates proteostasis imbalances in the cytosol

161 and nucleus

162 Next we investigated the quality control supply in the nucleus and cytosol in the context of disease-

163 related protein misfolding and aggregation. For this we co-expressed the biosensors with mutant 
bioRxiv preprint doi: https://doi.org/10.1101/2021.04.19.440383; this version posted April 19, 2021. The copyright holder for this preprint (which was not certified by peer review) is the author/funder, who has granted bioRxiv a license to display the preprint in perpetuity. It is made available under aCC-BY-NC-ND 4.0 International license.

164 Huntington exon 1 fragment containing 97 glutamines in the polyglutamine repeat sequence

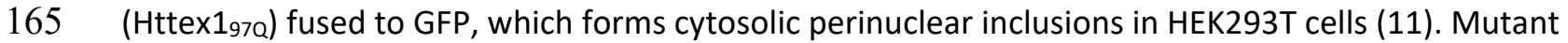
166 Httex1 fragments with polyglutamine sequences longer than 36 glutamines accumulate into inclusion bodies in neurons of Huntington Disease patients and have been implicated to direct a maladaptation in protein quality control (12). Because the fluorescence of GFP interferes with our capacity to monitor FRET, we used a variant of GFP that is non-fluorescent as characterized previously (13) and also added a 6 amino acid tetracysteine motif for post hoc detection by ReAsH biarsenical dye binding (14). Live cells were examined for inclusions, which were detectable as spherical pearl-like structures under transmission imaging of confocal microscopy, imaged for FRET and then post hoc analyzed by ReAsH staining to validate the inclusion structure. Because we needed to fix the cells after imaging, which reduces ReAsH staining, we were not able to ascertain cells containing only diffuse cytosolic Httex $1_{970}$. Using this approach, we observed the barnase biosensor as enriched at the periphery of the inclusions suggesting a degree of co-aggregation or corecruitment to the inclusions (Fig 4A). This was both true for the WT* barnase biosensor, which does not aggregate by its own volition, and for the nucleus-targeted biosensors suggesting that the biosensors were kinetically trapped on the surface of the Httex1 inclusion. To assess whether the

180 biosensor was self-aggregated at the molecular scale we determined their FRET using a ratiometric analysis of the fluorescence (Fig 4A). Indeed, the biosensor enriched at the inclusion periphery appeared to have higher FRET than when more distal from the inclusions in either the nucleus or cytosol. We further assessed the aggregation state using fluorescence recovery after photobleaching (FRAP) (Fig 4B). A small section of the biosensor was targeted for bleaching on the periphery of the Httex1 inclusion. Both nucleus and cytosol targeted biosensors showed little to no recovery after bleaching, indicating the protein was in an immobile state on the seconds timescale (Fig 4C).

Because the aggregation of the biosensor at the periphery of the inclusion is a confounding factor in whole cell fluorescence analysis by our flow cytometry methods, we instead measured FRET by microscopy targeting small subregions of the cells away from the inclusions. This analysis revealed that the presence of Httex $1_{97 Q}$ inclusions had no bearing on the FRET of the WT* barnase biosensor outside that associated with the inclusion periphery (Fig 4D). By contrast, the $188 \mathrm{G}$ barnase biosensor showed significantly changed FRET values regions outside the Httex197Q inclusions compared to cells without inclusions at all. In the case of the I88G barnase biosensor targeted to the

194 cytosol, the FRET was increased, which suggested a reduced overall holdase activity of chaperones in 195 the cytosol arising from Httex197a aggregation. However, in the case of the I88G barnase biosensor 196 targeted to the nucleus the FRET was decreased. This result is consistent with an elevated holdase 197 activity in the nucleus when $\mathrm{Httex} 1_{970}$ aggregates form. This result therefore suggests when protein 
bioRxiv preprint doi: https://doi.org/10 1101/2021.04 19.440383; this version posted April 19, 2021. The copyright holder for this preprint (which was not certified by peer review) is the author/funder, who has granted bioRxiv a license to display the preprint in perpetuity. It is made available under aCC-BY-NC-ND 4.0 International license.

198

199

200

201

202

203

204

205

206

207

208

209

210

211

212

213

214

215

216

217

218

219

220

221

222

223

224

225

226

227

228

229

230

aggregation occurs in the cytosol that cells can move the pool of quality control machinery from the cytosol into the nucleus as part of a global coordinated stress response.

\section{Discussion}

Our studies show that the balance of resources required to manage proteostasis is different in the cytosol relative to the nucleus. We find evidence for there being a lower supply of chaperone capacity in the nucleus that is able to bind to the unfolded barnase and prevent its aggregation. When we supplemented the cells with additional Hsp70 and Hsp40 protein by their overexpression (HSPA1A and DNAJB1), we increased holdase activity in the cytosol and lowered the aggregation potential consistent with these chaperones exerting a critical activity to bind unfolded proteins and prevent their aggregation. When we pharmacologically inhibited the Hsp70 chaperone system we observed a disproportionate impact on aggregation in the cytosol, concordant with the cytosol being more richly dependent on $\mathrm{Hsp} 40$ and $\mathrm{Hsp} 70$ chaperone-based networks to prevent protein aggregation.

Overall, these results are consistent with the greater requirement of the Hsp70 chaperone system to engage with unfolded or aggregation-prone proteins in the cytosol. This finding is consistent with the high abundance of these chaperones in the cytosol (8), which is not surprising given that most proteins are synthesized in the cytosol or endoplasmic reticulum.

Our findings with mutant $\mathrm{Httex} 1_{970}$ indicate that the aggregation in the cytosol can manifest dysfunction in quality control capacity in both the cytosol and nucleus. Consistent with prior findings that protein aggregation can sequester quality control resources away from "housekeeping" activities and lead to metastably-folded proteins aggregating (15), we found that the pool of resources binding to unfolded barnase biosensor decreased in the cytosol. Prior studies have found that Hsp70 and Hsp40 proteins are recruited into inclusions formed by Httex $1_{97 Q}$ and similar proteins with expanded polyglutamine sequences (16-19). One function for this recruitment may be disaggregation, in light of recent findings showing the Hsp70 based chaperone machinery can dissociate amyloid fibrils (20). More unexpected however was the finding that there was an increase in unfolded barnase in the nucleus, which suggests that chaperones are redirected into the nucleus under stress. Hsp70 is known to translocate from the cytosol into the nucleus upon heat shock (2123), suggesting there is a dynamic capacity for quality control machinery activity in the nucleus under times of stress. This translocation is regulated by the Hikeshi nuclear import carrier, which is crucial for cells to recover from heat shock stress (24). DNAJB1 can also deliver misfolded protein into the nucleus for degradation (25). 
bioRxiv preprint doi: https://doi.org/10 1101/2021.04 19.440383; this version posted April 19, 2021. The copyright holder for this preprint (which was not certified by peer review) is the author/funder, who has granted bioRxiv a license to display the preprint in perpetuity. It is made available under aCC-BY-NC-ND 4.0 International license.

231 The other notable result from our study was the recruitment of WT* barnase biosensor to the

232 Httex $1_{970}$ inclusion. We have never observed the wild-type* biosensor to aggregate when expressed

233 on its own suggesting that the inclusion provides a mechanism to recruit this protein to the surface.

234 One interesting possibility is that a small fraction of the biosensor remains in complex with

235 chaperones; and that these complexes are recruited to the surface of the inclusion by Hsp70 -based

236 triage mechanisms that more generally handle misfolded proteins in the cell. The different extent of

237 WT* biosensor foldedness in the nucleus compared to the cytoplasm supports the conclusion that

238 some of the wild-type barnase is partitioned from the equilibrium of folding in an unfolded-like

239 state. Discrete bodies containing misfolded protein including the JUNQ, aggresome and Q-bodies

240 have been proposed as cellular depots for processing protein aggregates, and are enriched with

241 different Hsp70 and Hsp40 proteins (26,27). In addition, Hsp70 has been proposed to engage with

242 the surface of protein aggregates to act as a disaggregase (20). Hence, the capture of wild-type*

243 biosensor may be indicative of a wider network of chaperone client interactions, protein aggregate

244 bodies in the cell and a broader interconnected quality control network. And thus chaperones may

245 have a broader function as a kind of lubricant constantly interfacing with unfolded proteins and

246 aggregating proteins.

\section{Materials and Methods}

248 Expression constructs. The cytosolic FRET barnase biosensor library expressed in the pTriEx4 vector 249 were prepared as previously described (5). In brief, the barnase moiety was flanked by circularly 250 permuted mTFP1 cp175 and Venus cp173 fluorescent proteins. Nuclear localised FRET barnase was 251 generated by the addition of a N-terminal SV40 NLS sequence to the original cytosolic barnase using 252 a synthesized gene cassette containing the relevant localization sequences (GeneArt (Thermofisher), 253 Waltham, Massachusetts) and standard restriction endonuclease-based ligation methods. For 254 generation of individual mutants of targeting biosensor, the WT* barnase biosensor kernel was replaced by the barnase mutant of choice. This was achieved by double-digestion of both the

256 desired barnase mutant and nuclear targeting construct plasmids at BamHI and Kpnl restriction 257 sites. The tetracysteine tagged Httex1 construct containing a tetracysteine tag at the C-terminus of 258 the Httex1 (TC1 (28)), and a non-fluorescent mutant of Emerald fluorescent protein (Em), Y66L (13), 259 was generated in-house to yield a plasmid named Httex1 ${ }_{970}$ TC1-Em Y66L in the pT-Rex vector

260 (Invitrogen). The pT-Rex Em Y66L construct alone was also generated in-house as described 261 previously (13). V5-tagged chaperone proteins were overexpressed from pcDNA5/FRT/TO V5 262 DNAJB1 and pcDNA5/FRT/TO V5 HSPA1A provided as gifts from Harm Kampinga (29).via Addgene, 263 Watertown, Massachusetts. 
bioRxiv preprint doi: https://doi.org/10 1101/2021.04 19.440383; this version posted April 19, 2021. The copyright holder for this preprint (which was not certified by peer review) is the author/funder, who has granted bioRxiv a license to display the preprint in perpetuity. It is made available under aCC-BY-NC-ND 4.0 International license.

Cell culture. HEK293T cells were maintained in DMEM supplemented with $10 \%(\mathrm{w} / \mathrm{v})$ fetal calf serum and $1 \mathrm{mM}$ glutamine in a $37^{\circ} \mathrm{C}$ humidified incubator with $5 \% \mathrm{v} / \mathrm{v}$ atmospheric $\mathrm{CO}_{2}$. Cells were seeded in poly-L-lysine coated plates. For microscopy experiments cells were plated at $3 \times 10^{5}$ cells $/ \mathrm{ml}$ in an 8 well $\mu$-slide (Ibidi, Martinsreid, Germany). For flow cytometry experiments cells were seeded at $1.1 \times 10^{5}$ cells $/ \mathrm{ml}$ in a 48 well plate. Cells were transiently transfected with Lipofectamine 3000 reagent as per manufacturer's instructions (Life Technologies, Thermofisher). For Barnase and Httex1 co-transfections, the transfection was done in a way to decouple the expression of the two plasmids.

HSP70 was inhibited with $20 \mu$ M VER-155008 (cat \#SML0271, Sigma-Aldrich, St. Louis, Missouri) in culture media for $18 \mathrm{~h}$.

Microscopy. Cells were imaged on a TCS SP5 confocal microscope (Leica Biosystems, Nussloch,

275 Germany). For immunofluorescence, cells were fixed in 4\% w/v paraformaldehyde for 15 mins at 276 room temperature, washed with phosphate buffered saline (PBS), and permeabilized in $0.5 \% \mathrm{v} / \mathrm{v}$

277 Triton X-100 in PBS (Sigma-Aldrich) for 30 mins. After incubation in blocking solution (5\% w/v bovine 278 serum albumin in 0.3\% v/v Triton X-100 in PBS), cells were incubated with anti-V5 (1:250 dilution in $2791 \% \mathrm{w} / \mathrm{v}$ bovine serum albumin in $0.3 \% \mathrm{v} / \mathrm{v}$ Triton X-100 in PBS) (cat \#ab27671, Abcam, Cambridge, 280 United Kingdom) overnight at $4^{\circ} \mathrm{C}$. Cells were then washed in $1 \% \mathrm{w} / \mathrm{v}$ ovine serum albumin in $0.3 \%$ v/v Triton X-100 in PBS before being stained with anti-mouse cy5 (1:500 dilution in PBS) for 30 min at room temperature. Prior to confocal imaging, cells were stained with Hoechst 33342

283 (ThermoFisher).

284 Image analysis. Confocal images were analysed using custom analysis scripts for FIJI (30) and 285 Python ( $v$ 3.6.7), available alongside example datasets at doi.org/10.5281/zenodo.4686851.

286 In the case of immunofluorescence measurements, whole cells and nuclei were initially identified 287 using the machine learning package CellPose (31). Segmentation was performed on the Cy5-labelled anti-V5 antibody and Hoechst channels (633 nm excitation, 650-750 nm emission and $405 \mathrm{~nm}$ excitation, 410-450 $\mathrm{nm}$ emission respectively) to identify the whole cell and nuclei regions of interest (ROI) respectively. Per-pixel information for each ROI was then collected and the nuclei ROIs removed from the whole cell to yield the cytosolic population. Finally, the fluorescence intensity for the nucleus and cytosol was determined from the mean of all pixels in each compartment. To quantify fluorescence recovery after photobleaching (FRAP), ROI for individual bleach spots were defined via automatic Otsu thresholding of the first bleaching frame. Identical ROI's were then manually placed for the adjacent (non-bleached) and background regions. Where necessary, ROI positions were manually adjusted across timepoints to account for cellular drift. The mean intensity 
bioRxiv preprint doi: https://doi org/10 1101/2021.04 19.440383; this version posted April 19, 2021. The copyright holder for this preprint (which was not certified by peer review) is the author/funder, who has granted bioRxiv a license to display the preprint in perpetuity. It is made available under aCC-BY-NC-ND 4.0 International license.

297 was calculated for each ROI, and both bleached and non-bleached ROIs were then corrected against 298 the corresponding background ROI for each time point, generating $B_{\text {corr }}$ and $N B_{\text {corr }}$ respectively. The ratio of $B_{\text {corr }} / N B_{\text {corr }}$ at each time point was finally normalised to the pre-bleach ratio of $B_{\text {corr }} / N B_{\text {corr }}$

300 to yield the relative recovery.

301 In the case of FRET measurements, whole cells, nuclei and Httex1 inclusions were initially identified using CellPose (31) as described above. In this case, segmentation was performed on the acceptor channel (488 $\mathrm{nm}$ excitation, 510-560 nm emission), computationally inverted acceptor channel and ReAsH channel (561 nm excitation, 610-680 nm emission) for whole cells, nuclei and inclusions respectively. After manual inspection to ensure the accuracy of each round of segmentation, perpixel intensity values for each ROI were collected. In the case of cytosolic barnase variants, both the nuclei and aggregate features were excluded from the whole cell to yield the diffuse barnase population. In the case of nuclear barnase variants, any aggregate ROI within the nuclei ROI were

309 similarly excluded to yield the diffuse barnase population. Finally, the relative FRET for each ROI was 310 calculated as the mean per-pixel intensity in the FRET channel (458 nm excitation, $510-560 \mathrm{~nm}$ 311 emission).

312 Flow cytometry. After $24 \mathrm{~h}$ (drug treatments) or $48 \mathrm{~h}$ (co-transfections) post-transfection, cells were 313 washed and harvested by gentle pipetting in PBS. Cells were analysed via flow cytometry as 314 described previously (6). In short, $150 \mu \mathrm{l}$ of cell suspension was analysed at flowrate of $3 \mu \mathrm{l} / \mathrm{sec}$ on a 315 BD LSRFortessa cell analyser (BD Biosciences, North Ryde, NSW, Australia). Acceptor (Venus) 316 fluorescence was collected with the $488 \mathrm{~nm}$ laser and FITC (530/30) filter. Acceptor sensitized 317 emission (FRET) and donor (mTFP1) fluorescence were collected with the $405 \mathrm{~nm}$ laser with PE 318 (575/25) and V500 (525/50) filters, respectively. All flow cytometry data were processed with FlowJo 319 (version 10, Tree Star Inc, Ashland, Oregon) to exclude cell debris, cell aggregates and untransfected 320 cells. The Venus channel was compensated to remove bleed through from mTFP1 and FRET channels 321 using donor only. Data were analysed in MATLAB (version 9, MathWorks, Natick, Massachusetts).

322 The gating strategy and associated data analysis protocols are detailed previously (32).

323 Urea denaturation curves. Urea denaturation curves were measured on cell lysates expressing the 324 biosensors in 96 well format. In essence, $80 \mu$ l of samples were prepared containing $0 \mathrm{M}$ to $8 \mathrm{M}$ urea 325 in PBS. Lysates were prepared from cells $24 \mathrm{~h}$ after transfection (wild-type* with NES and NLS tags) 326 by pipetting in $20 \mathrm{mM}$ Tris pH 8.0, $2 \mathrm{mM} \mathrm{MgCl}$, 1\% v/v Triton X-100, 1 × EDTA-free protease inhibitor 327 (Roche, Basel, Switzerland), $150 \mathrm{mM} \mathrm{NaCl}, 20 \mathrm{U} \mathrm{ml}^{-1}$ benzonase, $1 \mathrm{mM}$ PMSF. Aggregates and cell 328 debris were pelleted by centrifugation at $16,000 \mathrm{~g}$ for $10 \mathrm{~min}$ at $4^{\circ} \mathrm{C} .5 \mu \mathrm{l}$ supernatant was added to 329 each urea concentration. As the measurements were ratiometric and both fluorophores were on the 330 same molecule, samples were not matched for protein concentration. Fluorescence readings 
bioRxiv preprint doi: https://doi.org/10.1101/2021.04 19.440383. this version posted April 19, 2021. The copyright holder for this preprint (which was not certified by peer review) is the author/funder, who has granted bioRxiv a license to display the preprint in perpetuity. It is made available under aCC-BY-NC-ND 4.0 International license.

331 (430 nm excitation, $492 \mathrm{~nm}$ emission and $532 \mathrm{~nm}$ emission) were measured at $23^{\circ} \mathrm{C}$ using a

332 Clariostar microplate reader (BMG Labtech, Mornington, Victoria, Australia) every $15 \mathrm{~min}$ for $4 \mathrm{~h}$.

333 Relative FRET efficiencies (calculated as Acceptor fluorescence/[Donor fluorescence + Acceptor

334 fluorescence]) were averaged across readings and fit to a two-state unfolding model as described

335 previously (6).

336 
bioRxiv preprint doi: https://doi.org/10.1101/2021.04.19.440383; this version posted April 19, 2021. The copyright holder for this preprint (which was not certified by peer review) is the author/funder, who has granted bioRxiv a license to display the preprint in perpetuity. It is made available under aCC-BY-NC-ND 4.0 International license.

\section{References}

338 1. Schneider, K., and Bertolotti, A. (2015) Surviving protein quality control catastrophes--from cells to organisms. J. Cell Sci. 128, 3861-3869

2. Knowles, T. P., Vendruscolo, M., and Dobson, C. M. (2014) The amyloid state and its association with protein misfolding diseases. Nat Rev Mol Cell Biol 15, 384-396

3. Bertram, L., and Tanzi, R. E. (2005) The genetic epidemiology of neurodegenerative disease. J. Clin. Invest. 115, 1449-1457

4. Hipp, M. S., Park, S. H., and Hartl, F. U. (2014) Proteostasis impairment in protein-misfolding and -aggregation diseases. Trends Cell Biol. 24, 506-514

5. Wood, R. J., Ormsby, A. R., Radwan, M., Cox, D., Sharma, A., Vöpel, T., Ebbinghaus, S., Oliveberg, M., Reid, G. E., Dickson, A., and Hatters, D. M. (2018) A biosensor-based framework to measure latent proteostasis capacity. Nature Communications 9, 287

6. Wood, R. J., Ormsby, A. R., Radwan, M., Cox, D., Sharma, A., Vopel, T., Ebbinghaus, S., Oliveberg, M., Reid, G. E., Dickson, A., and Hatters, D. M. (2018) A biosensor-based framework to measure latent proteostasis capacity. Nat Commun 9, 287

7. Serrano, L., Kellis, J. T., Jr., Cann, P., Matouschek, A., and Fersht, A. R. (1992) The folding of an enzyme. II. Substructure of barnase and the contribution of different interactions to protein stability. J. Mol. Biol. 224, 783-804

8. Finka, A., and Goloubinoff, P. (2013) Proteomic data from human cell cultures refine mechanisms of chaperone-mediated protein homeostasis. Cell Stress Chaperones 18, 591605

9. Kampinga, H. H., and Craig, E. A. (2010) The HSP70 chaperone machinery: J proteins as drivers of functional specificity. Nature Reviews Molecular Cell Biology 11, 579-592

10. Schlecht, R., Scholz, S. R., Dahmen, H., Wegener, A., Sirrenberg, C., Musil, D., Bomke, J., Eggenweiler, H. M., Mayer, M. P., and Bukau, B. (2013) Functional analysis of Hsp70 inhibitors. PLoS One 8, e78443

11. Ramdzan, Y. M., Trubetskov, M. M., Ormsby, A. R., Newcombe, E. A., Sui, X., Tobin, M. J., Bongiovanni, M. N., Gras, S. L., Dewson, G., Miller, J. M. L., Finkbeiner, S., Moily, N. S., Niclis, J., Parish, C. L., Purcell, A. W., Baker, M. J., Wilce, J. A., Waris, S., Stojanovski, D., Bocking, T., Ang, C. S., Ascher, D. B., Reid, G. E., and Hatters, D. M. (2017) Huntingtin Inclusions Trigger Cellular Quiescence, Deactivate Apoptosis, and Lead to Delayed Necrosis. Cell Rep 19, 919927

12. Cox, D., Raeburn, C., Sui, X., and Hatters, D. M. (2020) Protein aggregation in cell biology: An aggregomics perspective of health and disease. Semin. Cell Dev. Biol. 99, 40-54

13. Olshina, M. A., Angley, L. M., Ramdzan, Y. M., Tang, J., Bailey, M. F., Hill, A. F., and Hatters, D. M. (2010) Tracking mutant huntingtin aggregation kinetics in cells reveals three major populations that include an invariant oligomer pool. J. Biol. Chem. 285, 21807-21816

14. Ramdzan, Y. M., Polling, S., Chia, C. P., Ng, I. H., Ormsby, A. R., Croft, N. P., Purcell, A. W., Bogoyevitch, M. A., Ng, D. C., Gleeson, P. A., and Hatters, D. M. (2012) Tracking protein aggregation and mislocalization in cells with flow cytometry. Nat Methods 9, 467-470

15. Gidalevitz, T., Ben-Zvi, A., Ho, K. H., Brignull, H. R., and Morimoto, R. I. (2006) Progressive disruption of cellular protein folding in models of polyglutamine diseases. Science 311, 14711474

16. Mitsui, K., Nakayama, H., Akagi, T., Nekooki, M., Ohtawa, K., Takio, K., Hashikawa, T., and Nukina, N. (2002) Purification of polyglutamine aggregates and identification of elongation factor-1alpha and heat shock protein 84 as aggregate-interacting proteins. J. Neurosci. 22, 9267-9277

17. Hay, D. G., Sathasivam, K., Tobaben, S., Stahl, B., Marber, M., Mestril, R., Mahal, A., Smith, D. L., Woodman, B., and Bates, G. P. (2004) Progressive decrease in chaperone protein levels in a mouse model of Huntington's disease and induction of stress proteins as a therapeutic approach. Hum. Mol. Genet. 13, 1389-1405 
bioRxiv preprint doi: https://doi org/10.1101/2021.04 19.440383; this version posted April 19, 2021. The copyright holder for this preprint (which was not certified by peer review) is the author/funder, who has granted bioRxiv a license to display the preprint in perpetuity. It is made available under aCC-BY-NC-ND 4.0 International license.

18. Seidel, K., Meister, M., Dugbartey, G. J., Zijlstra, M. P., Vinet, J., Brunt, E. R., van Leeuwen, F. W., Rub, U., Kampinga, H. H., and den Dunnen, W. F. (2012) Cellular protein quality control and the evolution of aggregates in spinocerebellar ataxia type 3 (SCA3). Neuropathol. Appl. Neurobiol. 38, 548-558

19. Radwan, M., Lilley, J. D., Ang, C. S., Reid, G. E., and Hatters, D. M. (2020) Immiscible inclusion bodies formed by polyglutamine and poly(glycine-alanine) are enriched with distinct proteomes but converge in proteins that are risk factors for disease and involved in protein degradation. PLoS One 15, e0233247

20. Nillegoda, N. B., Kirstein, J., Szlachcic, A., Berynskyy, M., Stank, A., Stengel, F., Arnsburg, K., Gao, X., Scior, A., Aebersold, R., Guilbride, D. L., Wade, R. C., Morimoto, R. I., Mayer, M. P., and Bukau, B. (2015) Crucial HSP70 co-chaperone complex unlocks metazoan protein disaggregation. Nature 524, 247-251

21. Pelham, H. R. (1984) Hsp70 accelerates the recovery of nucleolar morphology after heat shock. EMBO J. 3, 3095-3100

22. Welch, W. J., and Feramisco, J. R. (1984) Nuclear and nucleolar localization of the 72,000dalton heat shock protein in heat-shocked mammalian cells. Journal of Biological Chemistry 259, 4501-4513

23. Velazquez, J. M., and Lindquist, S. (1984) hsp70: nuclear concentration during environmental stress and cytoplasmic storage during recovery. Cell 36, 655-662

24. Kose, S., Furuta, M., and Imamoto, N. (2012) Hikeshi, a nuclear import carrier for Hsp70s, protects cells from heat shock-induced nuclear damage. Cell 149, 578-589

25. Park, S. H., Kukushkin, Y., Gupta, R., Chen, T., Konagai, A., Hipp, M. S., Hayer-Hartl, M., and Hartl, F. U. (2013) PolyQ proteins interfere with nuclear degradation of cytosolic proteins by sequestering the Sis1p chaperone. Cell 154, 134-145

26. Kaganovich, D., Kopito, R., and Frydman, J. (2008) Misfolded proteins partition between two distinct quality control compartments. Nature 454, 1088-1095

27. Sontag, E. M., Vonk, W. I. M., and Frydman, J. (2014) Sorting out the trash: the spatial nature of eukaryotic protein quality control. Curr. Opin. Cell Biol. 26, 139-146

28. Ramdzan, Y. M., Nisbet, R. M., Miller, J., Finkbeiner, S., Hill, A. F., and Hatters, D. M. (2010) Conformation sensors that distinguish monomeric proteins from oligomers in live cells. Chem. Biol. 17, 371-379

29. Hageman, J., and Kampinga, H. H. (2009) Computational analysis of the human HSPH/HSPA/DNAJ family and cloning of a human HSPH/HSPA/DNAJ expression library. Cell Stress Chaperones 14, 1-21

30. Rueden, C. T., Schindelin, J., Hiner, M. C., DeZonia, B. E., Walter, A. E., Arena, E. T., and Eliceiri, K. W. (2017) ImageJ2: ImageJ for the next generation of scientific image data. BMC Bioinformatics 18, 529

31. Stringer, C., Wang, T., Michaelos, M., and Pachitariu, M. (2021) Cellpose: a generalist algorithm for cellular segmentation. Nat Methods 18, 100-106

32. Hatters Danny, Wood Rebecca, Raeburn Candice, Ormsby Angelique, Mikael Oliveberg, and Alex, D. (2018) Measuring proteostasis capacity using transiently transfected bait proteins by flow cytometry. 28 March 2018, Protocol Exchange(Version 1) available at Protocol Exchange 
435 Table 1. Sequence overview of the barnase biosensor constructs*

pTriEx4 barnase WT* + NES

MAHHHHHHGSGEQKLISEEDLGSGSGSGGHHRVDFKTIYRAKKAVKLPDYHFVDHRIEILNHDKDYNKVTVYE SAVARNSTDGMDELYKGASGGMVSKGEETTMGVIKPDMKIKLKMEGNVNGHAFVIEGEGEGKPYDGTNTIN LEVKEGAPLPFSYDILTTAFAYGNRAFTKYPDDIPNYFKQSFPEGYSWERTMTFEDKGIVKVKSDISMEEDSFIYE IHLKGENFPPNGPVMQKKTTGWDASTERMYVRDGVLKGDVKHKLLLEGSGAQVINTFDGVADYLQTYHKLPD NYITKSEAQALGWVASKGNLADVAPGKSIGGDIFSNREGKLPGKSGRTWREADINYTSGFRNSDRILYSSDWLIYK TTDAYQTFTKIRAAAMDGGVQLADHYQQNTPIGDGPVLLPDNHYLSYQSALSKDPNEKRDHMVLLEFVTAAGIT LGMDELYKGGSGGMVSKGEELFTGVVPILVELDGDVNGHKFSVSGEGEGDATYGKLTLKLICTTGKLPVPWPTLV TTLGYGLMCFARYPDHMKQHDFFKSAMPEGYVQERTIFFKDDGNYKTRAEVKFEGDTLVNRIELKGIDFKEDGNI LGHKLEYNYNSHNVYITADKQKNGIKANFKIRHNIEGTDILQLKKLEEEELELDE

pTriEx4 barnase $W^{*}+$ NLS

MCGGGPKKKRKVEDPGGSGSGGHHRVDFKTIYRAKKAVKLPDYHFVDHRIEILNHDKDYNKVTVYESAVARN STDGMDELYKGASGGMVSKGEETTMGVIKPDMKIKLKMEGNVNGHAFVIEGEGEGKPYDGTNTINLEVKEG APLPFSYDILTTAFAYGNRAFTKYPDDIPNYFKQSFPEGYSWERTMTFEDKGIVKVKSDISMEEDSFIYEIHLKGE NFPPNGPVMQKKTTGWDASTERMYVRDGVLKGDVKHKLLLEGSGAQVINTFDGVADYLQTYHKLPDNYITKS EAQALGWVASKGNLADVAPGKSIGGDIFSNREGKLPGKSGRTWREADINYTSGFRNSDRILYSSDWLIYKTTDAY QTFTKIRAAAMDGGVQLADHYQQNTPIGDGPVLLPDNHYLSYQSALSKDPNEKRDHMVLLEFVTAAGITLGMD ELYKGGSGGMVSKGEELFTGVVPILVELDGDVNGHKFSVSGEGEGDATYGKLTLKLICTTGKLPVPWPTLVTTLGY GLMCFARYPDHMKQHDFFKSAMPEGYVQERTIFFKDDGNYKTRAEVKFEGDTLVNRIELKGIDFKEDGNILGHKL EYNYNSHNVYITADKQKNGIKANFKIRHNIEGTKDEL

436 *Sequences coded as: mTFP1 fluorescent protein (cp 175); WT* barnase; Venus fluorescent protein

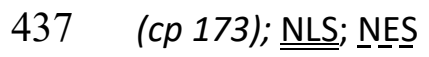


bioRxiv preprint doi: https://doi.org/10.1101/2021.04.19.440383; this version posted April 19, 2021. The copyright holder for this preprint (which was not certified by peer review) is the author/funder, who has granted bioRxiv a license to display the preprint in perpetuity. It is made available under aCC-BY-NC-ND 4.0 International license.

A

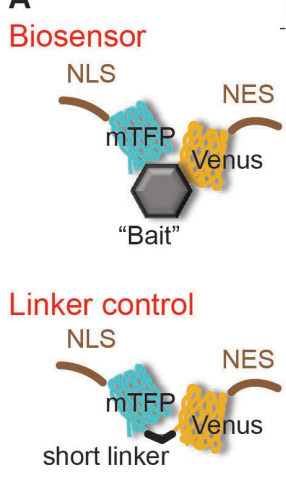

C
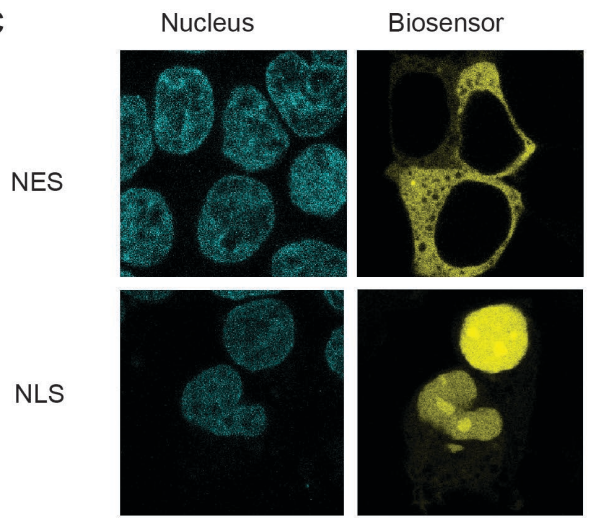

$50 \mu \mathrm{m}$

E

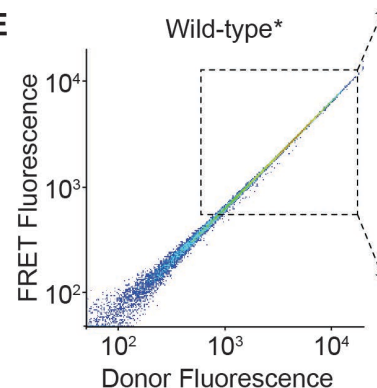

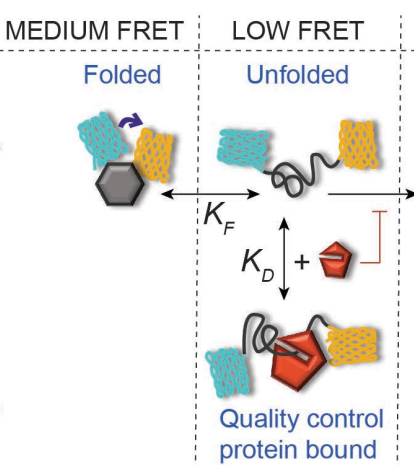

LOW FRET
HIGH FRET Aggregate

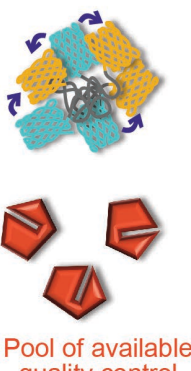

quality control

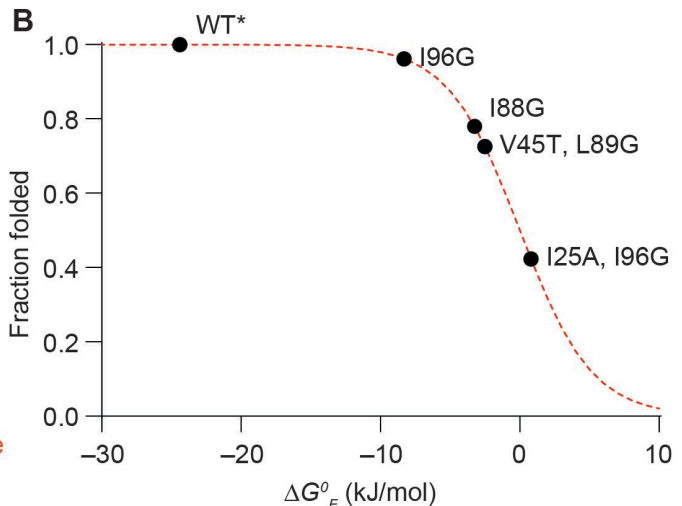

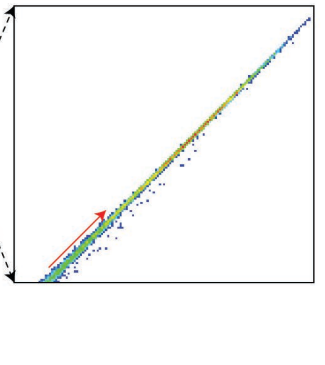

$10^{2}$

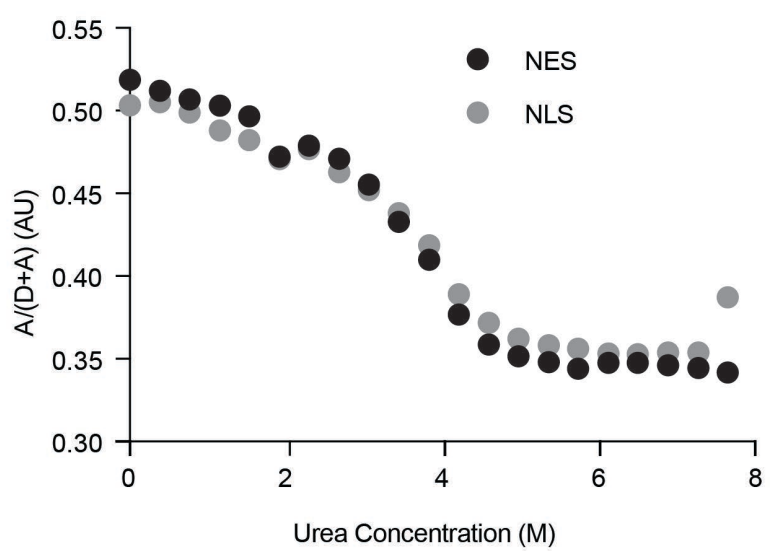

441 Figure 1: Targeting the barnase biosensor into the cytosol and nucleus. A. Schematic of how the

442 biosensor works. The barnase protein is used as the "bait" for chaperones and is flanked with

443 fluorescence proteins for Fluorescence Resonance Energy Transfer (FRET) measurements. A nuclear

444 localization sequence (NLS) or nuclear export sequence (NES) is appended to the construct. The

445 linker control has the barnase module omitted. B. Shown is the relationship between mutations in

446 barnase, the effect on standard free energy of folding $\left(\Delta G_{F}^{\circ}\right.$ at $\left.20^{\circ} \mathrm{C}\right)$, and predicted fraction folded

447 for the various biosensor variants used in the study. Wild-type (WT) barnase is marked with * to

448 denote it contains the catalytic inactivation mutation H102A. This mutation is present in all

449 constructs in the study. C. Confocal images of HEK293T cells transiently transfected with either

450 nuclear- or cytosol-targeting biosensor variant of the WT* barnase biosensor. The nucleus was

451 visualized by Hoechst 33342 stain (cyan) and biosensor by Venus fluorescent protein fluorescence

452 (yellow). D. Urea denaturation curves of WT* barnase biosensor variants as measured in cell lysates 
bioRxiv preprint doi: https://doi.org/10.1101/2021.04 19.440383; this version posted April 19, 2021. The copyright holder for this preprint (which was not certified by peer review) is the author/funder, who has granted bioRxiv a license to display the preprint in perpetuity. It is made available under aCC-BY-NC-ND 4.0 International license.

453 by FRET. E. Flow cytometry strategy for monitoring foldedness and aggregation. Here the donor and 454 acceptor fluorescence of cells were measured by channels (FRET and Donor fluorescence was gated 455 by the PE (575/25) and V500 (525/50) filters, respectively with the $405 \mathrm{~nm}$ laser). The inset

456 highlights the changes that arise for cells bifurcated into "upper" and "lower" slope populations

457 (division shown with red arrow). Representative cells collected from gates corresponding to the

458 upper and lower slope populations imaged by confocal microscopy (grayscale). The orange dashed 459 line denotes the nucleus boundary and the cyan dashed line the cell boundary.

460

461 
bioRxiv preprint doi: https://doi.org/10.1101/2021.04.19.440383; this version posted April 19, 2021. The copyright holder for this preprint (which was not certified by peer review) is the author/funder, who has granted bioRxiv a license to display the preprint in perpetuity. It is made available under aCC-BY-NC-ND 4.0 International license.

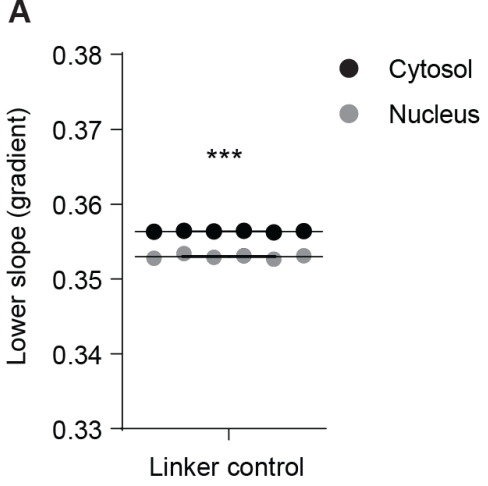

B

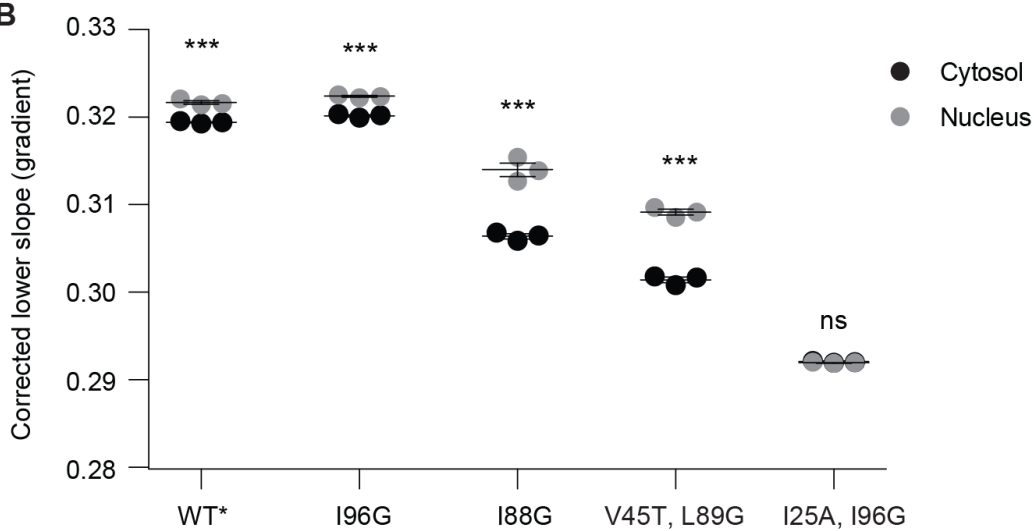

C
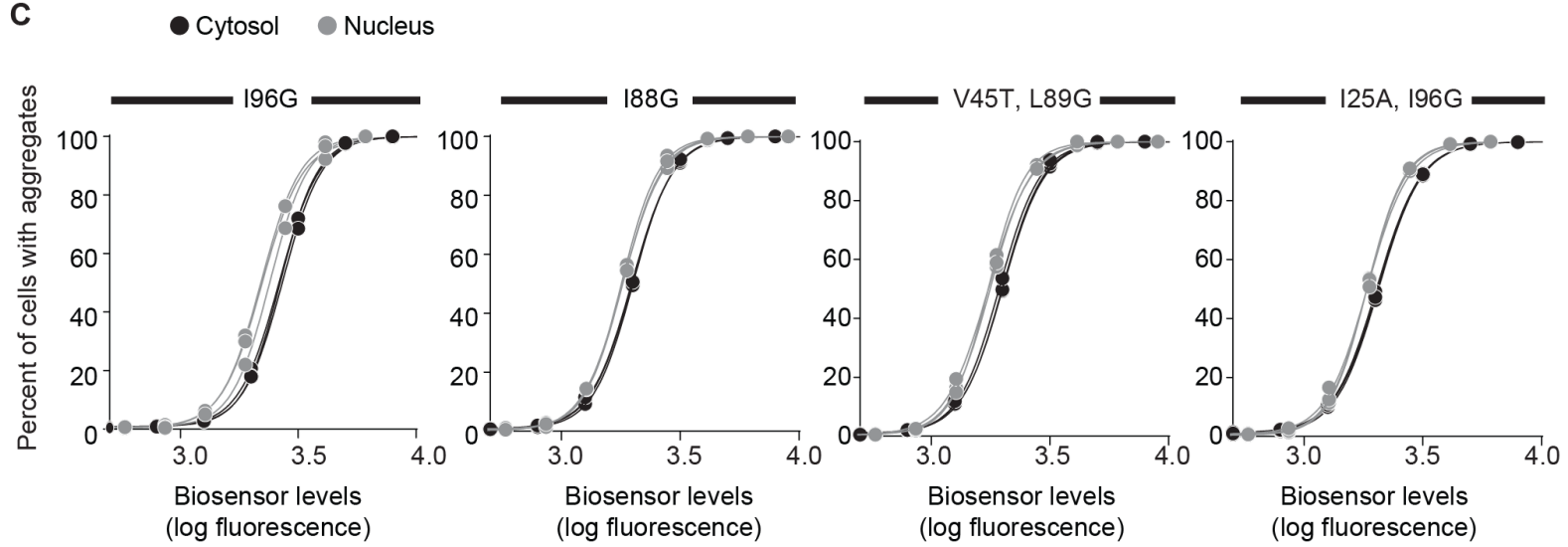

D

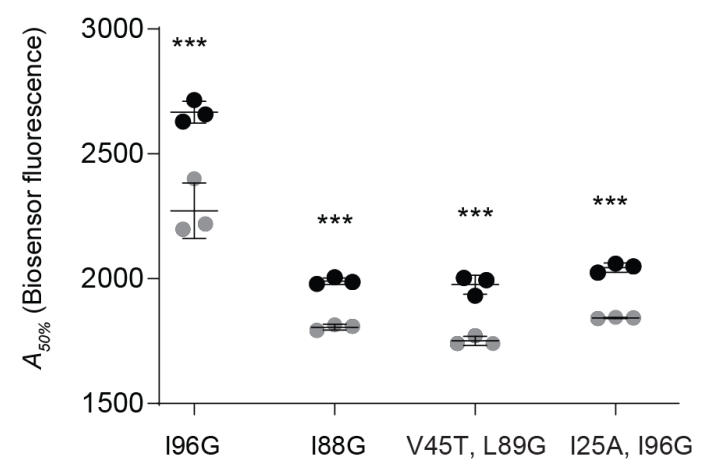

- Cytosol

- Nucleus

Figure 2: Reduced proteostasis resilience in the nucleus compared to the cytosol. All data in this

464 figure relate to NLS or NES-tagged biosensor constructs transfected in HEK293 cells and analysed by

465 flow cytometry. Individual biological replicates shown with means \pm S.D. and with differences

466 (nucleus $v$ cytosol) assessed by Student's t-test (2-tailed); ${ }^{* *} p<0.001$, ns $=>0.05$. A. Effect of

467 intrinsic FRET differences in nucleus versus cytosol assessed with the linker control. B. Analysis of

468 different barnase mutations. All data were corrected for background effects using the linker control.

469 C. Assessment of aggregation. Shown are cells binned into different biosensor levels (based on

470 Venus fluorescence) and each bin assessed for percent in upper slope versus lower slope

471 populations. Curves are fits to Hill equation. Data were fitted independently within each replicate

472 dataset $(n=3)$. D. Shown are biosensor concentrations at which $50 \%$ of cells have aggregates $\left(A_{50 \%}\right)$,

473 derived from the Hill equation fits shown in panel $\mathrm{C}$. 
A

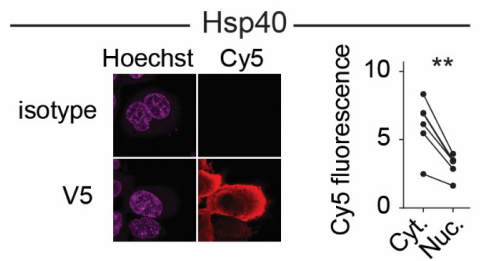

B

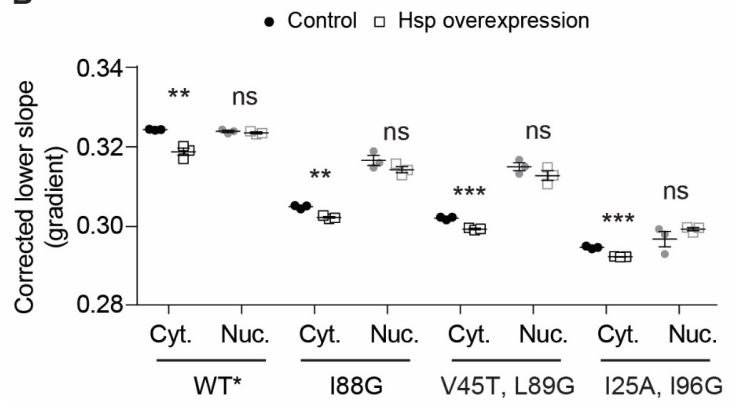

D

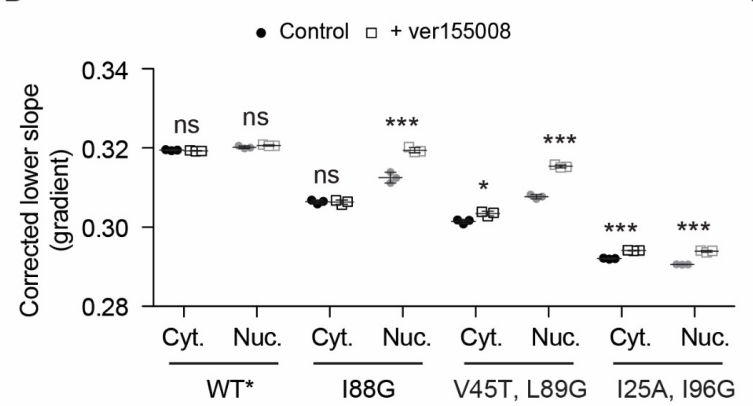

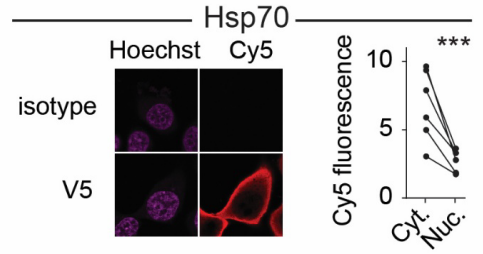

C

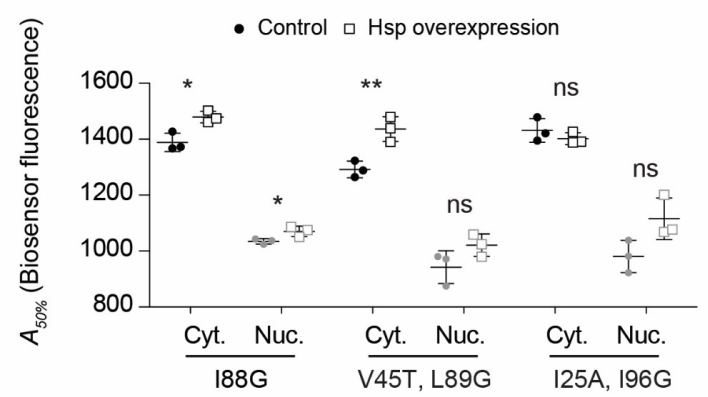

E

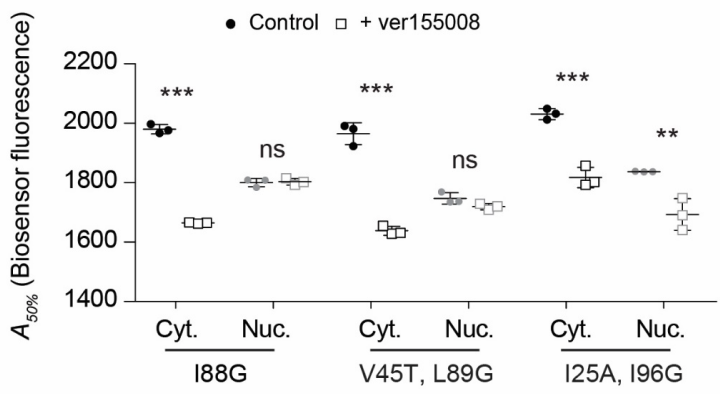

Figure 3: Cytosolic Hsp70 and Hsp40 activity provide depth in proteostasis resistance against

476 protein misfolding and aggregation. A. Shown are immunofluorescence micrographs of HEK293T

477 cells transiently transfected with either V5-tagged Hsp40 or Hsp70 proteins (DNAJB1 and HSPA1A

478 respectively). The nucleus is stained with Hoechst 33342 and chaperone with Cy5 labelled anti-V5 antibody (or isotype control for specificity). Graphs indicate quantitation with paired Student's t-test results shown (2-tailed, paired); ${ }^{* *} p<0.001,{ }^{* *} p<0.01$. Data points represent immunofluorescence intensity in single cells (paired by mean cytosol and mean nucleus). B. Lower slope analysis by flow cytometry of HEK293 cells co transfected with the biosensors, DNAJB1 and HSPA1A or control (a non-fluorescent derivative of GFP (Y66L Emerald (13)) for 48 hours. Data points indicate biological replicates, bars indicate means \pm S.D. Student's t-test results are shown (2-tailed; control v overexpression); ${ }^{* * *} p<0.001, * * p<0.01, * p<0.05$, ns $=>0.05$.

C. Aggregation analysis

$486\left(A_{50 \%}\right)$ using the same treatments and conditions as for panel B. D. Lower slope analysis of HEK293 cells after transfection with the biosensors for 18 hours and a further treatment with $20 \mu \mathrm{M} \mathrm{Hsp70}$ inhibitor VER-155008 for $18 \mathrm{~h}$ (versus vehicle control). Data is presented as per panel B. E. Aggregation analysis as presented for the other panels above. 
bioRxiv preprint doi: https://doi.org/10.1101/2021.04.19.440383; this version posted April 19, 2021. The copyright holder for this preprint (which was not certified by peer review) is the author/funder, who has granted bioRxiv a license to display the preprint in perpetuity. It is made available under aCC-BY-NC-ND 4.0 International license.

A

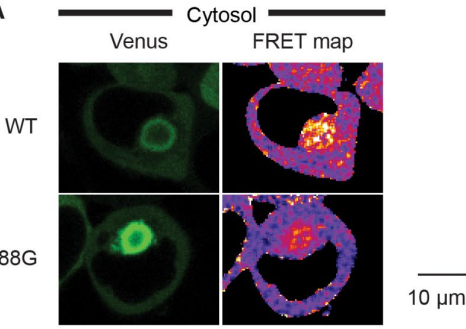

B

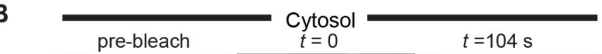

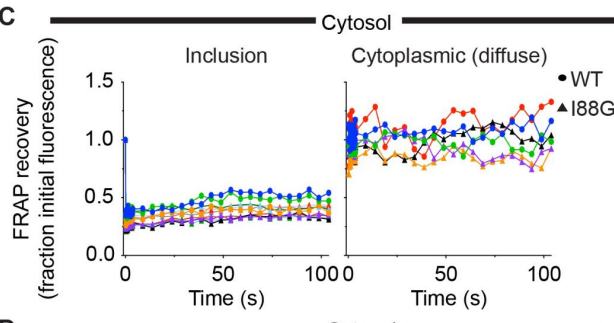

D

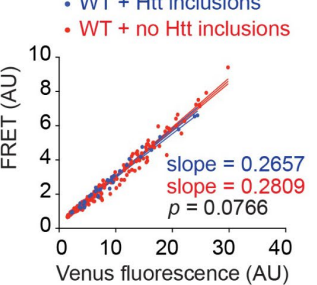

- $188 \mathrm{G}+\mathrm{Htt}$ inclusions

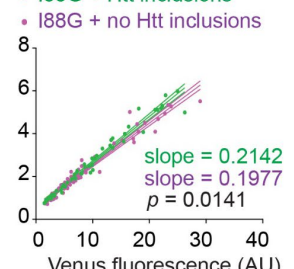

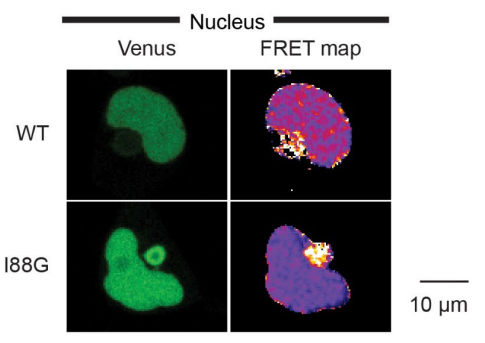
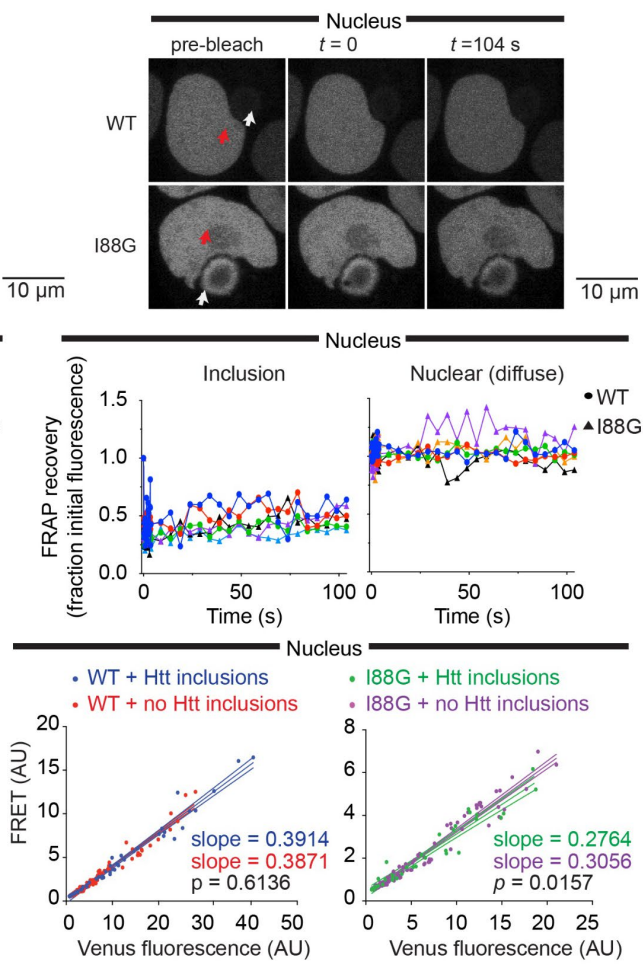

491 Figure 4: Huntingtin exon 1 aggregation in the cytosol manifests proteostasis imbalances in the

492 nucleus and cytoplasm. A. Confocal micrographs showing the values proportional to the

493 fluorescence ratio of acceptor/donor (Venus/mTFP) of the biosensors co-expressed with mutant

494 Httex $1_{970}$ fused to a non-fluorescent mutant of GFP. Selected cells are those with Httex1 inclusions,

495 identified post-hoc as described in the methods. Nuclear targeted biosensors are on the right and

496 cytosolic targeted biosensors on the left (same format for each panel). The scale of the FRET map is

497 colour coded from blue to magenta to yellow corresponding to lowest to highest FRET. B.

498 Fluorescence recovery after photobleaching (FRAP) of biosensor at the periphery of the $\mathrm{Httex} 1_{970}$

499 inclusion. Arrows indicate region of bleaching. C. Quantitation of the data in panel B, tracking the

500 recovery of fluorescence in the bleached zone. Each colour depicts the time course of an individual

501 cell. D. Confocal microscopy FRET fluorescence values within cells distal to the inclusion. FRET

502 fluorescence was measured by exciting at 458nm (mTFP1 excitation) and collecting the emission at

503 510-560 nm (Venus emission). Each dot represents the average fluorescence derived from a single

504 cell value. Solid lines show line of best fit from a linear regression with dashed lines showing $95 \%$ confidence intervals. P-value was determined by two-tailed t-test. 